\title{
THE IMPACT OF THE LISBON TREATY ON THE DEVELOPMENT OF EU IMMIGRATION LEGISLATION
}

\begin{abstract}
Lehte Roots*
Summary: Although the status of the Lisbon Treaty is still pending, the possible impact that it can have on the EU's immigration legislation is worth analysing and discussing. The importance of immigration, asylum and border control is evident in the fact that the topic is presented as early as in Article 3 of Title I of the Common Provisions of the Lisbon Treaty. It states that the Union 'shall offer its citizens an area of freedom, security and justice'. The common area is supposed to exist without internal frontiers where the free movement of persons is ensured. In order to provide for these rights, measures should be taken in the field of border control, asylum, immigration and the prevention and combating of crime, as immigration raises problems in all these fields. The internal market is mentioned only after the issues of migration. The aim of this paper is to discuss whether or not these changes and the Lisbon Treaty can lead to the better management of immigration at the EU level and to see where Europe is heading in this regard. Competences, legislation making, and objectives are discussed in order to find answers to questions about the development of common EU immigration legislation.
\end{abstract}

\section{Introduction}

Although its status is still pending, the possible impact of the Lisbon Treaty ${ }^{1}$ on the European Union's immigration legislation merits analysis and discussion. It can be said that the most recent stage of migration regulation at the EU level started with the introduction of the Lisbon Treaty (previously named the Constitutional Treaty). With the Policy Plan adopted on 21 December 2005, ${ }^{2}$ which primarily focused on economic immigration, the Commission fulfilled the mandate given to it by the Hague Programme. This is already in line with the objectives of the Lisbon strategy. ${ }^{3}$

\footnotetext{
* $\mathrm{PhD}$ candidate in law, European University Institute.

1 Treaty of Lisbon amending the Treaty on European Union and the Treaty establishing the European Community [2007] OJ 306.

2 Commission (EC) 'Policy Plan on Legal Migration' COM (2005) 669 final, 21 December 2005.

3 The focus of the strategy was on three main issues: supporting knowledge and innovation; making Europe a more attractive place to invest and work; creating more and better jobs.
} 
The importance of immigration, asylum and border control is evident in the fact that they are presented in Article 3 of Title I of the Common Provisions of the TFEU ${ }^{4}$ where it is stated that the Union "shall offer its citizens an area of freedom, security and justice'. The common area is supposed to exist without internal frontiers, and free movement of persons should be ensured. In order to provide for these rights, measures need to be taken in the areas of border control, asylum, immigration, and the prevention of crime. Immigration raises problems in different fields of life. New immigrants are users of social, medical, and educational services which are consequently affected by immigration and the arrival of new settlers. At the same time, immigration to Europe is needed because of its ageing population and low fertility rates. Vacant work places also need to be filled. Furthermore, immigrants accepted by one EU Member State should have the right to move freely within the entire EU. This makes legislation making at the EU level a very sensitive issue since there is a lack of trust among some Member States on the implementation of policies and on ways of accepting new immigrants.

The Lisbon Treaty slightly changes the current structure of the Treaty establishing the European Community (TEC). After the principles, it deals with Union competence, non-discrimination, citizenship of the Union, the internal market, free movement of goods, customs union, agriculture and fisheries, free movement of persons, services and capital, workers, and the right of establishment.

The competence of the EU in immigration is shared by the Member States and is confirmed by the TFEU. ${ }^{5}$ This situation complicates the legislative initiative of the EU Commission. Although the new decision-making process is shifted to qualified majority voting in the Council and the European Parliament, the parties are given joint decision-making powers with the introduction of a co-decision procedure. ${ }^{6}$ This procedure is already applicable to the legislative procedures which deal with the management of illegal migration, but it will also be extended to legal migration legislative actions.

Article 5 TEC states that:

The Community shall act within the limits of the powers conferred upon it by this Treaty and of the objectives assigned to it therein. In

\footnotetext{
4 For the purposes of this article, the Lisbon changes and the numbering of articles referred to are taken from the Consolidated Version of the Treaty on the Functioning of the European Union (further referred to as TFEU) <http://eur-lex.europa.eu/LexUriServ/LexUriServ.do?uri=OJ:C:2008:115:0047:0199:EN:PDF> accessed 5 October 2009.

5 TFEU arts 1, 4-5, 76.

6 The name of co-decision will disappear. After the adoption of the Lisbon Treaty, this will be called the 'ordinary legislative procedure'.
} 
areas which do not fall within its exclusive competence, the Community shall take action, in accordance with the principle of subsidiarity, only if and in so far as the objectives of the proposed action cannot be sufficiently achieved by the Member States and can therefore, by reason of the scale or effects of the proposed action, be better achieved by the Community. Any action by the Community shall not go beyond what is necessary to achieve the objectives of this Treaty.

The competence issue is not currently mentioned in the immigration or asylum provisions. Instead, concrete guidance is given in Articles 61-69 related to which rules should be adopted at the EU level. Does the Lisbon Treaty change anything? Will immigration legislation at the EU level be more effective compared to the current rules? The effectiveness of the common policy is difficult to determine and might be assessed only after the measures are applied. The fears of the Member States about losing control over immigration is evident from Article 79 (5) of the Lisbon Treaty which specifies that the quantity of immigrants is under the discretion of Member States. This article gives quite broad legislative options in other fields. ${ }^{7}$ The voting procedure in the field of legal immigration has also been changed from unanimous to qualified majority voting (QMV). In the case of illegal immigration, QMV already applies.

The aim of this paper is to discuss whether or not these changes really will lead to the better management of immigration at the EU level and it will also ask where Europe is heading with regard to immigration management legislation.

\section{Objectives}

The Lisbon Treaty establishes as an objective a common policy in the area of immigration. The EU has to take action on the 'efficient management of migration flows', 'fair treatment' of legally residing third-country nationals, 'prevention' and enhanced combating of illegal immigration and trafficking in human beings. ${ }^{8}$ The aim of the Lisbon Treaty, as mentioned in its preamble, is to develop legislation which ensures a uniform status of asylum for nationals from third countries which is valid throughout the Union, and to ensure the rights of third-country nationals who are residing legally in Member States. The current directives and regulations are intended to ensure that there are common asylum procedures and

\footnotetext{
7 Art 79(5) states: 'This Article shall not affect the right of Member States to determine volumes of admission of third-country nationals coming from third countries to their territory in order to seek work, whether employed or self-employed'.

8 TFEU art 79.
} 
qualifications for refugees in all EU Member States. This objective was not provided for in the TEC. Article 63 TEC states which measures the Council has to adopt in the areas of immigration, asylum, refugees, and measures in the area of immigration policy that define the rights and obligations of third-country nationals who are legally resident in Member States.

Asylum, immigration and border checks are dealt with in Chapter 2 of the Treaty of Lisbon under Title V called the Area of Freedom, Security and Justice. Furthermore, Title V is expanded to cover more issues than it did in the TEC. Simultaneously, along with immigration, asylum and border checks, it also covers cooperation of the police (chapter 5) and in civil (chapter 3) and criminal (chapter 4) matters between Member States. The provisions on police and judicial cooperation in criminal matters, considered to belong to the third pillar of the EU, are currently covered by the Treaty on European Union (TEU) under Title VI articles 29-42. In comparison with the current TEC, there are new provisions on measures against illegal immigration which are related to the conclusion of re-admission agreements with third countries. Article 63(3)b mentions 'repatriation of illegal residents' as one of the measures to be taken, but does not explicitly talk about re-admission agreements with third countries.

The EU is already active in these measures. Many political decisions were made a long time ago. ${ }^{9}$ Recently, several readmission agreements have been concluded with Russia, Albania, and Ukraine. These are considered to be tools for fighting against illegal immigration. In addition, financial help is provided by some Member States. For example, financial help from Italy to Libya keeps irregular immigrants in Libya and therefore protects Italy from a mass influx of asylum seekers. ${ }^{10}$ This shows the EU's intention to outsource problems of illegal immigration to neighbouring countries. Whether this is a successful immigration control measure is debatable.

Trafficking in persons is currently mentioned in Article 29 TEU which deals with police and judicial cooperation in criminal matters. As we have said, this is part of the third pillar. Likewise, trafficking is provided for in the TFEU in article 83 under the provisions on criminal matters. However, the TFEU also places 'trafficking in persons' under article 79(1) which provides for the development of a common immigration policy. Previous treaties did not deal with trafficking in persons as an immigration issue,

\footnotetext{
9 Tampere European Council, Presidency Conclusions, 15-16 October 1999.

${ }^{10}$ Read more in <http://www.timesofmalta.com/articles/view/20090531/local/libya-askseu-for-1bn-to-combat-immigration> and <http://www.newser.com/article/d98603pg3/italy-gives-libya-3-boats-to-patrol-for-migrants.html>. Both sites accessed on 28 September 2009.
} 
as this was mainly a matter for police cooperation in criminal matters. Consequently, the issue of trafficking is no longer considered only as a matter for police cooperation in criminal matters, but instead becomes part of a common immigration policy which has to be legislated for under the EU immigration framework.

The TFEU also emphasises the fair treatment of third-country nationals who are residing legally in Member States, ${ }^{11}$ This is not highlighted in this way in the current Treaty.

Regarding illegal immigration, legislation already exists on the recognition of expulsion decisions, ${ }^{12}$ on the facilitation of unauthorised entry and residence, ${ }^{13}$ carriers' obligations, ${ }^{14}$ victims of trafficking, ${ }^{15}$ carrier sanctions, ${ }^{16}$ the return of immigrants, ${ }^{17}$ and proposed directives on employer sanctions. ${ }^{18}$

When reading the new policy measures introduced by Lisbon, one feels that all the practical areas, which are already in place, are now just legislated for in primary legislation. There are no substantial changes. This casts doubt on the originality or novelty of these measures. However, it is a positive development that current practice will be legislated for in primary legislation. This gives the area of Freedom, Security and Justice more bases for further development and will create confidence that the practice can have an influence on the development of primary legislation.

11 TFEU art $63 \mathrm{a}$ and the Consolidated Version of the Treaty art 79 (1).

12 Council Directive (EC) 2001/40 on the mutual recognition of decisions on the expulsion of third-country nationals (EC Expulsion directive) [2001] OJ L 149.

13 Council Directive (EC) 2002/90 defining the facilitation of unauthorised entry, transit and residence [2002] OJ L 328.

14 Council Directive (EC) 2004/82 of 29 on the obligation of carriers to communicate passenger data [2004] OJ L 261.

15 Council Directive (EC) 2004/81 on the residence permit issued to third-country nationals who are victims of trafficking in human beings or who have been the subject of an action to facilitate illegal immigration, who cooperate with the competent authorities [2004] OJ L 261 .

16 Council Directive (EC) 2001/51 supplementing the provisions of Article 26 of the Convention implementing the Schengen Agreement of 14 June 1985 [2001] OJ L 187.

17 European Parliament and Council Directive (EC) 2008/115 on the common standards and procedures in Member States for returning illegally staying third-country nationals [2008] OJ L 348.

18 Proposal for a Directive of the European Parliament and of the Council providing for sanctions against employers of illegally staying third-country nationals COM (2007) 249 final, 16 May 2007. 


\section{Main changes in legal framework}

The most fundamental change of the TFEU regarding the reform of Justice and Home Affairs (JHA) is the replacement of the existing three pillars with one legal framework in a single legal text. It should be mentioned that the Common Foreign and Security Policy continues to have intergovernmental procedures while third pillar policies will be assimilated within the first pillar.

The TFEU removes the existing split within the JHA domain between asylum, immigration, border controls, and judicial cooperation in civil matters which currently fall under Title IV of the TEC (first pillar), and judicial cooperation in criminal matters and police cooperation which falls under Title VI of the TEU (third pillar). Chapter 2 of Title V of the Treaty of Lisbon focuses on asylum, immigration, and border checks. Articles 77-80 regulate this issue. The idea is to develop a policy to ensure the absence of any controls on persons, whatever their nationality, when crossing internal borders. This not only improves the travelling possibilities for EU citizens but also for third-country nationals or stateless persons who have accessed the EU or who live in one Member State. However, it also facilitates the movement of irregular or illegal migrants within the EU, although this is not its purpose. When a third-country national enters a Schengen Member State, he or she can move without any border control to another Schengen Member State. Although there has been a great deal of harmonisation at the EU level to legislate the access of third-country nationals to the EU, the implementation of these EU norms in Member States still differs. It is easier to access some Member States than others. The very restrictive and selective process of legal immigration gives rise to irregular immigration. ${ }^{19}$ Weaker states, which have less control, are used to access targeted countries.

Another major new restriction on EU action is imposed by Article 79(5) of the TFEU. This provides that Member States will fully keep their right to determine their 'volumes of admission' of third-country nationals for work purposes. This applies to both employed and self-employed persons. Member States are still interested in keeping the power to maintain immigration quotas (where they already exist), although this does not have any practical value. While in the EU, people have the right to move freely within the EU and in practice can work illegally in another state by obtaining a residence permit from another state which might have more

\footnotetext{
19 I use the term irregular immigration because not all migrants are illegal. Illegal immigration refers to something related to criminality, which is not always the case of persons who are moving. For more about this terminology, see Khalid Koser 'Irregular Migration, State Security and Human Security' September 2005 <http://www.gcim.org/attachements/TP5. pdf> accessed 10 August 2009.
} 
favourable rules for issuing a permit. The labour market tends to regulate itself. When there is no work and there are no favourable conditions for settling in a country, people simply do not come. A perfect example of a failed quota system that still exists is in Estonia where for many years the immigration quota has not been reached. There are fewer residence permit applications than the quota allows.

\section{The role of the institutions - Council, Commission, Parliament and Court}

Monar argues that the previously drafted Constitutional Treaty, which was the basis for the TFEU, gives the Union the ability to act internally and externally as a single legal actor with a single set of legal instruments. ${ }^{20} \mathrm{He}$ also points out that the principle of primacy of EU law over national law ${ }^{21}$ would encourage uniformity. This is currently not clearly obvious under Title VI of the TEU.

According to the TFEU, the actors in the area of freedom, security and justice are the Union, the Council, the European Council, National Parliaments, the European Parliament, the Commission, representatives of Union bodies, ${ }^{22}$ and the relevant departments of the Member States. ${ }^{23}$

In the current system, the Council is the main actor in issuing new legislation. The Commission and the European Parliament and the departments and administration of the Member States are mentioned in Article 66 TEC. Currently, national parliaments do not play any kind of role in legislative or policy-making procedures at the EU level. The role of the Commission as an initiator of draft legislation is not sufficiently visible in the current Treaties.

Although the TFEU refers many times to 'the Union', it is unclear what or who the implementing and enforcing body of 'the Union' is. In the case of border checks, asylum and immigration, and for the purposes of paragraph 1 of Article 77 and Article 78(1), the measures are adopted by the European Parliament and the Council. The Council can act unanimously after consulting Parliament to adopt provisions concerning passports, identity cards, residence permits, or any other such documents. In these cases, the provisions are adopted through special legislative procedures. ${ }^{24}$

\footnotetext{
$20 \mathrm{~J}$ Monar, 'The reforms in the justice and home affairs domain: the end of the "third pillar"?' in F Laursen (ed), Rise and Fall of the EU's Constitutional Treaty (Nijhoff/Brill, Leiden 2008).

21 Constitutional Treaty arts 1-6

22 TFEU art 71.

23 TFEU art 74.

24 TFEU art 77(3).
} 
Special powers are given to the Council in the case of emergency, such as a sudden inflow of nationals of third countries. In these cases, the Council may adopt, after consulting European Parliament provisional measures, proposals by the Commission, for the benefit of the concerned Member States. This procedure, though, seems to be very complicated and makes one wonder if the decisions or measures can be made within a reasonable period of time if all the EU institutions are involved in this decision-making process. The idea of transparency and involving all parts is certainly welcome and might be important, but it seems to lack the efficiency needed in these kinds of emergency cases.

The role of the Commission is explicitly mentioned only in the case of a massive inflow, in which case it is to make proposals for provisional measures. Normally, all references to legislative procedures by implication incorporate reference to the Commission.

The role of the Parliament is mentioned more often in the TEC. The European Parliament acts together with the Council in adopting measures on:

a) a common policy on visas and short stay residence permits;

b) external border checks;

c) conditions under which third-country nationals have freedom to travel within the Union;

d) an integrated management system for external borders; ${ }^{25}$

e) the uniform status of asylum for third-country nationals which is valid throughout the Union;

f) the uniform status of subsidiary protection for those who are in need of international protection;

g) a common system of temporary protection for displaced persons in the event of a massive inflow;

h) common procedures for the granting and withdrawing of uniform asylum or subsidiary protection status;

i) criteria and mechanisms for determining which Member State is responsible for considering applications for asylum or subsidiary protection;

j) standards concerning the conditions for the reception of applicants for asylum or subsidiary protection; 
k) partnership and cooperation with third countries for the purpose of managing inflows of people applying for asylum or subsidiary or temporary protection; ${ }^{26}$

1) conditions of entry and residence, and Member State standards on long-term visas and residence permits, including family reunion;

$\mathrm{m})$ the definition of the rights of third-country nationals residing legally in a Member State, including the conditions governing freedom of movement and of residence in other Member States;

n) illegal immigration and unauthorised residence, including removal and repatriation of persons residing without authorisation;

o) combating trafficking in persons, in particular women and children; ${ }^{27}$

p) promoting the integration of third-country nationals residing legally in their territory. ${ }^{28}$

As this long list shows, the European Parliament must have competence in the areas of asylum, visas, long-term residents, removal, and trafficking. This creates new challenges for Members of Parliament who need to be updated on current problems and how to tackle them. The role of the European Parliament has never been so precisely explained as in the TFEU. The Parliament should be consulted when the Council acts in accordance with special legislative procedures to adopt provisions concerning passports, identity cards, residence permits, or any other such documents. ${ }^{29}$

\section{European Court of Justice}

The Treaty of Amsterdam gave the European Court jurisdiction over all Justice and Home Affairs measures. However, there are still differences between the issues of immigration, asylum and civil law (Article 68 TEC) and the issues of policing and criminal law (Article 35 TEU). Jurisdiction over these matters is the subject of special rules.

The jurisdiction of the European Court of Justice (ECJ) over matters of immigration and asylum is more limited than in other areas, where Community law applies. The distinctive rules governing ECJ jurisdiction over immigration are currently set out in Article 68 TEC. Article 68(1) TEC provides that Article 234 TEC, concerning preliminary rulings from

\footnotetext{
26 TFEU art 78(2).

27 TFEU art 79(2).

28 TFEU art 79(5).

29 TFEU art 77(3).
} 
national courts, applies in the following way to the issues, which fall within the scope of Title IV of the TEC:

... where a question on the interpretation of this title or on the validity or interpretation of acts of the institutions of the Community based on this title is raised in a case pending before a court or a tribunal of a Member State against whose decisions there is no judicial remedy under national law, that court or tribunal shall, if it considers that a decision on the question is necessary to enable it to give judgment, request the Court of Justice to give a ruling thereon.

Furthermore Article 68(2) provides that: 'In any event, the Court of Justice shall not have jurisdiction to rule on any measure or decisions taken pursuant to Article 62(1) relating to the maintenance of law and order and the safeguarding of internal security'.

It is not possible for a national court or tribunal of first instance or an ordinary appeal court to refer a question of interpretation of Community law in these matters to the Court of Justice for a preliminary ruling unless it is really considered to be the final court. The claimant must first exhaust all national remedies before the Community Court can be asked to interpret the relevant law. This system does not facilitate the uniform application of EU immigration and asylum legislation throughout Europe as it does in other areas of EC law. It also does not help to develop European principles of immigration and asylum and practically deprives wide categories of people (eg asylum seekers, applicants for family reunification, and third-country nationals challenging expulsion orders or discriminatory treatment) of effective judicial protection.

The ECJ has held since Wachauf ${ }^{30}$ that Member State acts which implement or apply Community law fall within the scope of Community law and must therefore comply with the general principles of Community law. Battjes argues that the same reasoning applies to the accordance of Member States implementing acts to the Refugee Convention and other relevant treaties and that this falls within the scope of the review under Article 63(1). ${ }^{31}$ Article 63(1) TEC therefore renders the ECJ competent to review the compliance of Member States' legislation with the Refugee Convention and other international agreements. This, of course, is only when the court implements EU law. Meanwhile, another question emerges before the courts as they have to take into account international, national and EU legislation applicable to the case.

\footnotetext{
30 Case C-5/88 Wachauf v Bundesamt für Ernährung und Forstwirtschaft (ECJ 13 July 1989).

31 H Battjes, European Asylum Law and International Law (Martinus Nijhoff Publishers, Leiden/Boston 2006) 98.
} 
Since a direct individual appeal to the ECJ in asylum or immigration matters is not possible, individuals need to search for protection before domestic courts. According to Article 68 TEC, when read in conjunction with Article 234, domestic courts can ask preliminary questions on the interpretation of the TEC. This includes questions on the requirement of accordance with the Refugee Convention and other relevant treaty law. However, a restriction contained in Article 68(1) determines that in this area only courts against whose decision there is no further right of appeal are entitled to submit preliminary references. So, in asylum and immigration cases, access to the ECJ is limited to the supreme courts of the Member States, unless the first or second instance court is considered to be a court of final instance for the claims in the relevant case. This has an adverse effect on the unity of Community law in the field of asylum and immigration since it will take more time for questions on interpretation to be referred to the Court. Many cases of interpretation of European common rules on immigration and asylum do not reach the ECJ. This situation creates a diverse application of EU asylum and immigration laws, as Member States have the power to interpret EU legislation according to their own interests. This means there is no common practice in the EU in implementing EU asylum and immigration legislation.

The ECJ can supervise the interpretation and application of instruments of international law. This is of particular interest as regards the Refugee Convention, since there is no treaty or monitoring body which can address the application of the Convention in individual cases. ${ }^{32}$ Furthermore, Article 63(1) TEC establishes that

The Council ....shall.....adopt measures on asylum, in accordance with the Refugee Convention of 28th July 1951 and the Protocol of 31 January 1967 relating to the status of refugees and other relevant treaties.

The only problem, as mentioned earlier, is that the review is really restricted. The scope of the review is limited to Member State acts which fall within the scope of Community law. Only acts which implement or apply directives and regulations issued by the EU on asylum fall under the scope of Community law. The EU is not part of the 1951 Refugee Convention and its Protocol of 31 January 1967. The fact, though, is that most immigration and asylum issues are also covered or will be covered by the EU. If a Member State applies protection standards which are not in conformity with the Refugee Convention, the ECJ can give a preliminary ruling that the domestic law is not in accordance with the interpretation of Community legislation.

32 Battjes (n 31) 605. 
In the TFEU, the European Court of Justice will have a bigger role since the current restrictions will be abolished. There is no special provision in the current treaty's Article 68, which is simply repealed by the TFEU. This can create an influx of cases related to asylum and immigration for the ECJ. The abnormal situation where the application of EU law in the Member States cannot be contested in front of the most competent institution (ECJ) will be changed from the current system ${ }^{33}$ which prohibits national courts other than those of final instance from applying to the Court for preliminary rulings. The normalisation of the jurisdiction of the Court of Justice in Justice and Home Affairs matters (called the Area of Freedom, Security and Justice in the TFEU) is a positive development.

The Commission drafted a Council Decision to propose the normalisation of this situation, and the final document was completed on 28 June 2006. ${ }^{34}$ This should have been enforced on 1 January 2007. The Council Decision says that

With effect from [1 January 2007], Article 234 of the Treaty shall apply to any request made to the Court of Justice by a national court to rule on a question concerning the interpretation of Title IV of Part Three of the Treaty or on the validity and interpretation of acts of the Community institutions on the basis of that Title, including requests made before [1 January 2007] on which the Court of Justice has not yet ruled at that date.

With effect from [1 January 2007], the second sentence of the third subparagraph of Article 2(1) of the Protocol integrating the Schengen acquis into the framework of the European Union shall cease to apply in matters to which Community law applies.

With effect from [1 January 2007], Article 68 of the Treaty shall cease to apply.

According to Article 67(2), the Council had to consult the European Parliament with its decision. ${ }^{35}$ The Parliament approved the draft Council Decision in its consultation procedure. But the final Council Decision has not been agreed upon because of resistance by some Member States. However, the TFEU will in any case solve this problem. The current Treaty allows only the use of the preliminary ruling system in immigration

\footnotetext{
33 TEC art 68(1).

34 Commission (EC) 'Adaptation of the provisions of Title IV of the Treaty establishing the European Community relating to the jurisdiction of the Court of Justice with a view to ensuring more effective judicial protection' COM (2006) 346 final 28 June 2006.

35 European Parliament legislative resolution of 25 April 2007 on the draft Council Decision adapting the provisions concerning the Court of Justice in fields covered by Title IV of Part Three of the Treaty establishing the European Community (COM(2006)0346 - C60304/2006 - 2006/0808(CNS)).
} 
cases, provided that this request comes from the court of last instance of the Member State. ${ }^{36}$

\section{Legal instruments}

The current Treaty provision for dealing with legal instruments is Article 249 TEC. Its first paragraph lists the names of the legislative acts: these are regulations, directives, decisions, recommendations and opinions, all issued by the joint actions of the Council, Commission and Parliament. This is certainly not a complete list of legal instruments which the EU uses today. There are numerous soft law instruments, sui generis decisions or general decisions. These are not the same as the decisions mentioned in Article 249 TEC. Sometimes, the sui generis decisions are underestimated in EC law. They are used for detailed institutional arrangements in the internal operation of the EU, such as laying down rules of procedure or setting up new committees or new administration bodies or action programmes in all kinds of policy areas. The use of a particular instrument is not clearly related to the types of EC competence.

The central distinction between regulations and directives, which was originally intended to express distinctions between supranational areas of Community policy, has now, in practice, lost that meaning. Currently, regulations that are directly applicable are more often adopted in the First Pillar. Directives can also now be directly applicable, and both instruments are used today almost interchangeably in all areas of EC law. The Treaty definition of a directive (with its reference to the Member States' choices of form and methods of transposition) is no longer seen to be expressing a limit of competence.

The TFEU aims to put an end to this complex and unclear list of legislative instruments. According to Article 288 of the TFEU, Union competences will be exercised by the institutions through regulations, directives, decisions, recommendations, and opinions.

Regulations are generally applicable, binding, and directly applicable in all Member States. A directive is binding upon the Member State to which it is addressed. A decision is binding in its entirety. There is not much difference in the list of the names of the legal acts stated in Article 249 TEC and Article 288 of the TFEU. The difference becomes clearer when the articles of the TFEU are read further. Legal acts that are adopted by legislative procedure compose a group of legislative acts. ${ }^{37}$ In specific cases, the legislative acts can be adopted, for example, by a group

\footnotetext{
36 TEC art 68.

37 TFEU art 289(3).
} 
of Member States. The adjective 'delegated' should be inserted in the tile of the delegated acts ${ }^{38}$ and the word 'implementing' should be inserted in the title of the implementing acts. ${ }^{39}$ All other regulations, directives, and decisions without either of these two adjectives in their titles will normally be legislative acts. This should clarify the function and power of the acts adopted at the EU level, and especially in the areas of immigration and asylum.

\section{Legislative procedure and decision making}

In general, the TFEU does not change legislative decision making. The procedures laid down in Articles 249 to 256 TEC are elaborated in Part Six under Title Chapter 2 which contains two sections. The second section is called 'procedures for the adoption of acts and other provisions'. There will be no major changes in the procedures themselves, but the relative importance of the various procedures will alter. As before, there will be no single legislative procedure to issue EU legislation. The co-decision procedure is called the "ordinary legislative procedure ${ }^{\prime 40}$ and all other procedures are called 'special legislative procedures'. Co-decision will be extended to new areas of policy making and, therefore, the change of name can be justified. This includes areas like agriculture, external trade, police and criminal justice cooperation, and also legal migration. The ordinary legislative procedure (previously co-decision) will become the main procedure for adopting EU legislation. The exception to this rule, which can also affect immigration legislation decision making, is the so-called 'emergency brake' which allows single Member States to suspend their ordinary legislative procedures and refer the file for discussion to the European Council level. ${ }^{41}$

As already mentioned, in the Lisbon Strategy, according to the ordinary legislative procedure, a common policy (not a legal framework or cooperation) on visas and other short-stay residence permits shall be adopted. Under the ordinary legislative procedure, the European Parliament and the Council shall adopt measures for a common European asylum system which comprises the following: a uniform status of asylum and subsidiary protection for third-country nationals; a common system of temporary protection for displaced persons in the event of a massive inflow; common procedures for the granting and withdrawing of uniform asylum or subsidiary protection status; criteria and mechanisms for de-

\footnotetext{
38 TFEU art 290(3).

39 TFEU art 291(4).

40 TFEU art 289(1).

41 Under art 82(3) of the TFEU, when the State considers that a draft directive would affect fundamental aspects of its criminal justice system.
} 
termining which Member State is responsible for considering an application for asylum or subsidiary protection; standards concerning the conditions for the reception of applicants for asylum or subsidiary protection; and partnership and cooperation with third countries for the purpose of managing inflows of people applying for asylum or subsidiary or temporary protection. ${ }^{42}$ The power of the Union is to define status and criteria, standards, and to design systems and common procedures. Partnerships and cooperation with third countries has never before been regulated by primary legislation as a tool to combat immigration.

The TFEU also foresees decision making in cases where one of the Member States is confronted with an emergency situation characterised by a sudden inflow of third-country nationals. In this kind of situation, the Council has the power to adopt provisional measures for the benefit of the Member State or States concerned. The proposal must come from the Commission, and the European Parliament must be consulted. ${ }^{43}$

Currently, the Commission adopts acts of an executive nature, so that it mainly uses regulations (for generally applicable measures) or decisions (for individual measures), although it also adopts implementing directives. Whether the legislative measure should be legislated by the Council acting alone, or by the Parliament and Council acting jointly, depends on the prescribed decision-making procedure. In policy areas where co-decision applies, the acts are adopted by the Parliament and Council jointly; in other areas, acts are adopted by the Council. In general, there is no connection between the type of legal instrument and the use of a particular procedure in decision making. However, when the title of a directive, regulation or decision indicates that it was adopted "by the European Parliament and Council', it is possible to conclude that the codecision procedure was used.

The current system of pillars means different decision-making processes occur in the first and third pillars. The divide will be reduced, but not abolished, by the TFEU's provisions. For example, the qualified majority rule will now apply with regard to the control of the Union's external borders and asylum. The Union will therefore be able to harmonise the rules governing the granting of asylum. Co-decision by the European Parliament with majority voting in the Council, which is currently applied in most of the first pillar areas, but not under the third pillar, will become the standard decision-making procedure in the current Justice and Home Affairs domain. This will make it possible to put an end to the complex system whereby various rules are mixed and are inapplicable

\footnotetext{
42 TFEU art 78(2).

43 TFEU art 78(3).
} 
in the various Union Member States and will help to develop a common asylum policy.

The treaty also strengthens the European Union's means to fight against illegal immigration and the trafficking of human beings. Again, decisions will be taken by qualified majority in 'co-decision' with the European Parliament. This means that there will be a common policy applied by the Union. Substantial parts of police and judicial cooperation in criminal matters will still be governed by the existing unanimity requirement and the European Parliament which was granted the right of co-decision on most of the issues under the first pillar but is limited to giving assent or to being consulted on other issues falling under Justice and Home Affairs.

So, from the decision-making point of view, the pillar system is actually maintained. It continues to exist at least to some extent. Monar is concerned that this kind of hidden continuation of the pillar separation also means the continuation of the problems of cross-cutting packages of measures due to different procedures, voting requirements, and forms of involvement of Parliament. ${ }^{44}$

Amato, however, is concerned about the new articles 62, 63 and 69A(2) which offer a legal basis for a directive establishing minimum legislation concerning the rights of individuals in criminal procedure and concerning the rights of victims of crime. He claims that

these clauses confer to the Union a legislative competence that goes beyond the pre-existing obligation not to violate human rights when regulating sectors under its jurisdiction. The promotion of human rights is necessarily included in such competence. Nor is the notion of 'minimum rules' inconsistent with the promotion of rights. ${ }^{45}$

As he clearly points out, minimum rules have substance and meaning as long as they enhance the pre-existing standards in those Member States with the lowest.

All measures concerning border controls, immigration, and asylum are shifted to a qualified majority vote in the Council. Meanwhile, the European Parliament is given joint decision-making powers with the introduction of the co-decision procedure. ${ }^{46}$

\footnotetext{
44 Monar (n 20) 82.

45 G. Amato, 'Foreword' in S Griller and J Ziller (eds), The Lisbon Treaty: EU Constitutionalism without a Constitutional Treaty? (Springer, Wien, New York 2008) viii.

46 S Peers, EU Immigration and Asylum Law: Text and Commentary, (Martinus Nijhoff, Boston/Leiden 2006) 68.
} 
As this analysis shows, there will be no single legislative procedures for the European Union after the TFEU. There will still be many cases in which the Treaty provides for special legislative procedures, mainly in 'intergovernmental' matters. In these cases, the Council will be the sole author of legislation and the Council will have to act by unanimity rather than by qualified majority.

\section{Competence}

Article III-264 of the Constitutional Treaty stated that the European Commission had the exclusive right of initiative for asylum, immigration, border control, and judicial cooperation in civil matters. Currently, the European Commission shares this right with the Member States under the third pillar. The TFEU gives the Union competence in developing a common policy on asylum, subsidiary protection, and temporary protection with a view to offering appropriate status to any third-country national requiring international protection and ensuring compliance with the principle of non-refoulement. This policy must be in accordance with the Geneva Convention of 28 July 1951 and the Protocol of 31 January 1967 relating to the status of refugees, and other relevant treaties. For this purpose, competence is given to the European Parliament and Council to adopt measures in the following areas:

- conditions of entry and residence, and standards on the issue by Member States of long-term visas and residence permits, including for the purpose of family reunification;

- the definition of the rights of third-country nationals residing legally in a Member State, including conditions governing freedom of movement and of residence in other Member States;

- $\quad$ illegal immigration and unauthorised residence, including removal and repatriation of persons residing without authorisation;

- combating trafficking in persons, in particular women and children.

The Union is given explicit competence to conclude agreements with third countries for the readmission to their countries of origin or provenance of third-country nationals who do not, or who no longer, fulfil the conditions for entry, presence or residence in the territory of one of the Member States. ${ }^{47}$

With a special legislative procedure, the Council, acting unanimously after consulting the European Parliament, may adopt provisions con-

47 The return directive was introduced for this purpose. 
cerning passports, identity cards, residence permits, or any other such documents. ${ }^{48}$ The development of EU ID cards and residence permits can only be welcomed. These will facilitate the better recognition of the right to move across borders. This is a clear increase in EU competence which has been considered as an area to be covered by the Member States.

At the same time, it seems that the Member States are seeking to shift competences in the field of Justice and Home Affairs slightly to their side by allowing cooperation or coordination outside the organisational framework of the EU, and hence without the involvement of the Council. Article 73 of the TFEU stipulates the right of Member States to enter 'between themselves' into 'such forms of cooperation and coordination' as they deem appropriate 'in order to safeguard national security'. The Council, Commission and Parliament seem to be out of the decisionmaking procedure and even without competence in cases where national security issues are involved. This encourages the Member States to act more quickly and proactively with emergency issues, thereby avoiding the long decision-making processes in the normal procedures. EU laws in general do not prohibit Member States from cooperating outside the EU framework, but it seems that Member States want to have special provisions under the current Justice and Home Affairs clauses for enhanced cooperation among themselves. As Kau argues

by insisting on adopting the right to enter into co-operation or co-ordination measures, this supplemental addition to the Lisbon Treaty does not enhance the Member States' sovereignty but rather emphasises their dependence on the explicit authorisation in the European Treaties. ${ }^{49}$

He claims that Article 73 of the TFEU does the opposite of what it was intended to do. I do not agree with his point of view. As I have already mentioned, EU Treaties do not prohibit additional cooperation among Member States.

There is another new aspect in legislation making and in the role of the Member States within it. When the EU adopts harmonisation measures by establishing minimum rules, or when it is supposed to act unanimously, any Member State can request that a draft be referred to the European Council if it 'would affect fundamental aspects of its criminal justice system'. In this case, the legislative procedure is suspended. ${ }^{50}$ If a compromise is not found within four months, there is a chance to save

\footnotetext{
48 TFEU art 77(3).

49 M Kau, 'Justice and Home Affairs in the European Constitutional Process - Keeping the Faith and Substance of the Constitution' in Griller and Ziller (n 45) 229.

50 TFEU arts 82(3) and 83(3).
} 
the legislation when 'at least nine Member States' wish to establish enhanced cooperation. This is currently stipulated in Articles 11 and 11 a TEC. The possibility of enhanced cooperation for a group of at least nine Member States is believed to reduce the bargaining power and obstructive potential of individual Member States.

Explicit Union competence in developing a common policy on asylum, subsidiary protection and temporary protection with a view to offering appropriate status to any third-country national requiring international protection and ensuring compliance with the principle of nonrefoulement is reaffirmed by the Lisbon Treaty. This policy must be in accordance with the Geneva Convention of 28 July 1951 and the Protocol of 31 January 1967 relating to the status of refugees, and other relevant treaties. Although competence is already present through Article 63 TEC, reconfirmation and new ways of introducing legislation are important since they can lead to new types of EU refugee status if harmonisation is enhanced.

\section{Conclusion}

The TFEU reaffirms the merging of Title VI of the TEU and Title IV of the EC Treaty. There are also changes to the decision-making process which shift several measures to qualified majority voting in the Council and which give the European Parliament joint decision-making powers by introducing an ordinary legislative procedure (previously called co-decision). Even so, the changes in the Justice and Home Affairs area seem to be more of a technical nature rather than amounting to substantial changes. Nevertheless, the rules in the TFEU constitute a further step in ongoing development in the field of Justice and Home Affairs of the EU. Some decades ago these were treated as the sole and sovereign matters of Member States. This analysis has shown that in recent years the rules have become more harmonised. The TFEU provides tools for further development in the harmonisation of immigration policies. Its shortcomings will emerge through practice when it is enforced but, until that time, the EU has to play with the old rules and do as much as possible to fulfil its tasks as given in the Treaties. In addition, the conditions under which third-country nationals will have the freedom for short-term travel within the Union should be defined. Currently, there is not enough support at the Community level. If persons are crossing internal borders, there should be no control, irrespective of nationality. Therefore, thirdcountry nationals who have the right to enter one country will also enjoy the provision on the free movement of persons. There seems to be a small conflict in the concept of free movement of third-country nationals. This is because the Schengen area does not cover the whole of the EU. 
The Treaty itself speaks of internal borders ${ }^{51}$ which should mean the EU internal borders and not the Schengen internal borders. The Schengen acquis is attached to the TFEU by the Protocol Integrating the Schengen acquis into the Framework of the European Union. The attachment of the Schengen acquis to the TFEU makes the free movement provisions more transparent and clear, even though they are applicable even now.

In the current Treaty, these aims are not specified. The topics concerning which the Council has had to take measures in the areas of immigration and asylum are simply listed. ${ }^{52}$ The Treaty acknowledges the competences of the Member States regarding the number of people who can be accepted into the EU. ${ }^{53}$ This provision does not make much difference, since the Member States cannot really control the movement and stop the further movement of persons who were admitted. It is possible, for example, for persons admitted into Germany to go on to France since the other articles of the Treaty refer to the free movement clause of third-country nationals who are admitted to one Member State. Article 77 of the TFEU in particular says that the Union shall develop a policy to ensure the absence of any controls on persons. So, in fact, the states do not control the flow of persons who have a right to reside in one Member State and who can therefore go to another Member State.

Looking back to the TEC and comparing it to Lisbon, it can be said that changes have occurred. The TFEU clarifies what can be done at the EU level, and the goals set are also made clearer. But, at the same time, some provisions that were in the TEC Agreement are not reflected in Chapter 2 of the TFEU. Previously, the policy covered by Title IV was called 'Visas, Asylum, Immigration and Other Policies Related to Free Movement of Persons'. Now, Chapter 2 of the TFEU deals with these issues under the title 'Policies on Border Checks, Asylum and Immigration'. This chapter falls under the area of Freedom, Security and Justice.

The TFEU has major implications for police and judicial cooperation in criminal matters, such as co-decision and qualified majority voting. The ECJ's jurisdiction will be extended to this area. ${ }^{54}$ The present Title IV of the TEU 'Visas, Asylum, Immigration and Other Policies related to

\footnotetext{
51 TFEU art 77(2)(e).

52 TEC arts 61, 62, 63.

53 TFEU article 79 (5). This Article shall not affect the right of Member States to determine volumes of admission of third-country nationals coming from third countries to their territory in order to seek work, whether employed or self-employed.

54 For more, see "Fighting Cross-border crime: EU Co-decision, QMV and ECJ Jurisdiction to be Extended into Area of Police and Judicial Cooperation [Article 61]' (amendment to Treaty of Lisbon amending the Treaty on European Union and the Treaty establishing the European Community (Lisbon, 13 December 2007)) <http://www.europeanfoundation. org/docs/Tuesday\%2029\%20January/ARTICLE\%2061.mht> accessed 12 March 2009.
} 
Free Movement of Persons' and the present Title VI of TEU 'Police and Judicial Cooperation in Criminal Matters' is replaced by Title IV 'Area of Freedom, Security and Justice'. With the Treaty of Amsterdam, 'visas, asylum, immigration' were transferred from the intergovernmental to the EC pillar, becoming subject to EU decision-making procedures and to the scrutiny of the European Court of Justice. 'Police and Judicial Cooperation in Criminal Matters' (third pillar) is presently subject to unanimity. The TFEU will abolish the Maastricht Treaty pillar structure and move 'Police and Judicial Cooperation in Criminal Matters' to the Treaty on the Functioning of the European Union (the existing EC Treaty). The new title 'Area of Freedom, Security and Justice' brings all of the presently dispersed JHA policies under one heading. The 'Community method' is extended to police and judicial cooperation in criminal matters.

The TFEU facilitates the Union's development of its own actions and policies concerning security and justice. It is clear that the ECJ will ensure that the common area of 'Freedom, Security and Justice' is not undermined. It transfers increased powers to the EU institutions, in the area of security and justice. Qualified Majority Voting in the Council of Ministers and co-decision (called 'ordinary legislative procedure') will be the rule. Hence, the European Parliament will have a stronger and more influential role. In 1997, the Treaty of Amsterdam incorporated a large part of the former third pillar into the EC Treaty. Consequently, the ECJ's powers concerning Title IV (Visas, Asylum, Immigration, Judicial Cooperation in Civil Matters) were established as equivalent to its powers for upholding and interpreting other Community law areas. Nevertheless, the ECJ's preliminary rulings on jurisdiction concerning these matters, according to Article $68 \mathrm{TEC}$, is restricted to national courts from which there is no judicial remedy. The TFEU repeals Article 68 TEC. 